\title{
GLOBE Program Association: Kollaboratív és innovatív tudásplatform a természetes hatóanyagok $\mathrm{K}+\mathrm{F}$ támogatásához
}

Polgár Tímea*, Lapusnyik Nóra, Horváth Péter

Envision Biotechnology Kft, www.envisionbiotechnology.com

*e-mail: timea.polgar@envisionbiotechnology.com

Az Egészségügyi Világszervezet becslése szerint Földünkön a betegek jelentős részét, legalább $80 \%$-át természetes szerekkel kezelik. A fejlett ipari országokban használatos gyógyszereknek jelentős része, hozzávetőleg 40\%-a származik természetes forrásokból, ez az arány még magasabb, ha a természetes eredetű származékokat is figyelembe vesszük.

A természetes molekulákon alapuló gyógyszerkutatás számos kihívása ellenére eredményesen járulhat hozzá a gyógyszerinnováció fellendüléséhez. A természetes molekulák a gyógyszerkutatási programok számára új kémiai szerkezeteket szolgáltathatnak, ezen felül a természetes gyógymódokban kódolt tudás hozzájárulhat releváns gyógyszercélpontok felfedezéséhez is.

Napjainkban a komplex megbetegedések és a gyógyszerkészítményekkel szemben támasztott magas követelmények kihívás elé állítják a gyógyszeripart. Az „egy target-egy betegség" koncepció a komplex megbetegedések kezelésére szolgáló gyógyszerek fejlesztésére számos nehézséggel küzd. Erre a célra több hatóanyagot tartalmazó, komplex készítmények lehetnek alkalmasak, amelyek a jelátviteli útvonalakkal számos ponton kölcsönhatnak. Ennek modellezéséhez, megértéséhez és a megfelelő komplex készítmények kifejlesztéséhez a tradicionális gyógymódokban rejlő tudás nyújthat segítséget.

A GLOBE Program Association a természetes molekulákra épülő kutatás támogatására és azok ipari alkalmazásainak segítésére alakult nonprofit szervezet. $\mathrm{A}$ GLOBE program egy olyan üzleti és tudományos piactér, ahol a terület megfelelő kutatóit a szervezet aktívan segíti üzleti és tudományos projektek és együttmúködések kialakításában. A program célul tűzi ki az akadémiai kutatási eredmények ipari fejlesztésekben történő alkalmazását, a fejlődő országokból származó tudás nyomon követését és az abból származó haszon igazságos elosztását. A program keretein belül a területre specifikus tudományos informatikai eszközök és területre specifikus tudásanyag kerül kifejlesztésre, amelyekből a tagok egyenlően részesülnek. 